\title{
Modeling the Aerodynamics and Performances of a Historic Airplane: the Spanish "Cuatro Vientos"
}

\author{
A. González-Betes, R. Martínez-Val
}

\begin{abstract}
The process of modeling the aerodynamics and performances of a historic airplane is very similar to the conceptual and preliminary design phases of a new plane, with the advantage of knowing the configuration and that the airplane was airworthy; thus it is unnecessary to outline and assess many different alternatives. However, the drag polar, the real performances, stability features, etc, are still unknown. For various reasons (in particular because of two World Wars, or the Civil War in the Spanish case) most details of many historical airplanes have been lost.

In the present research work, the situation is as follows. In June 1933 the "Cuatro Vientos", a Spanish-built Bréguet XIX Super TR, flew non-stop from Seville to Cuba; a distance of $7500 \mathrm{~km}$ (about 4100 nautical miles) in around 40 hours. A few days later, in a far less complicated stage between Havana and Mexico, the airplane was lost with its occupants to a storm in the Yucatan peninsula.

The modeling considered in this paper starts by addressing the aerodynamic modifications introduced in the airplane for the extremely long flight. Then, with the help of old and present day aerodynamic data and methods the drag polar is estimated. The available engine data is completed and extrapolated to obtain information on power and fuel consumption. Finally, all this data is integrated to provide a reliable and technically sound reproduction of the Seville-Cuba flight.
\end{abstract}

Keywords: historic airplanes, airplane performances.

\section{Introduction}

Only a couple of decades after the first successful flight of the Wright brothers, the 1920s and 1930s were years of enormous advances in aviation. The Great War had ended and many enthusiasts could use the large surplus of airplanes left behind. Aviation was becoming popular in many countries and aeronautics was establishing the sound scientific and technical basis required for the astonishing development aviation has had up to the present day [1].

This period corresponds to the time of the Grand Raids that were stimulated by the search for fame, rewards, national glory, political impulse or the establishment of new commercial routes. As nowadays, the North Atlantic track received the greatest attention, since it lay between the two areas of the world with the highest economic and technical development [2]. The geography and meteorology produce some bias in favour of west-to-east flights between the east coast of the USA and Canada on the one hand, and Ireland or Great Britain on the other [2]. A few flights can be noted among the many remarkable achievements:

- Vicecmdr. Read with Curtiss NC4 from Newfoundland to the Azores, Lisbon and Plymouth, in May 1919;

- Alcock and Brown, aboard a Vickers Vimy, flew for the first time non-stop between America and Europe in June 1919;

- Lindbergh, on a Ryan Special, boosted aviation to the newspaper headlines with his solo flight from New York to Paris in May 1927;

- Von Hünefeld, Koehl, Spinder and Fitzmaurice crossed for the first time east-west from Berlin to Ireland and to Labrador in April 1928 with a Junkers W33L;

- Costes and Bellonte crossed from Paris to New York in September 1930, now from the European mainland in a Bréguet XIX Super TR;
- Amelia Earhart, flew the second solo flight (first for a woman) from America to Europe, in May 1932, in a Lockheed Vega.

The Mid and South Atlantic routes were less important from the economic point of view, but much more challenging in terms of distance to be covered, adverse meteorology and the absence or scarcity of suitable airfields along the track. However, for Spanish and Portuguese pilots these links represented fame and glory [3]. So, as early as in 1922, Cabral and Coutinho tried a flight from Portugal, just arriving and crashing on the Brazilian coast. In January 1926, Ramón Franco, Durán and Rada flew in a Dornier Wal hydroplane from Seville to Buenos Aires with a few stops in West Africa and Brazil. Iglesias and Jiménez flew more than 3000 nautical miles (almost a world record) to reach Brazil non-stop from Spain in March 1929 [3, 4].

\section{Preparing the grand raid}

The section above describes the ambience and the level of the technology and achievements before 1932. In this euphoric environment the Spanish aviator Captain Mariano Barberán conceived an incredible flight from Spain to Cuba: almost $8000 \mathrm{~km}$, to be continued until Mexico in a second stage: a mere $1900 \mathrm{~km}$ extra.

Captain Barberán was a very well prepared and highly trained airman of this period. At the age of only 30, in 1925, he had participated in the preparation of the "Plus Ultra" flight from Seville to Buenos Aires [3-6] although, for various reasons, he did not finally fly on board $[3,4]$. In the early 1930s he was appointed the Head of the Aviation Observers School at Cuatro Vientos airfield, in the outskirts of Madrid. And, then, the idea of a world record flight to the Caribbean region fuzzily appeared. Captain Barberán first convinced 
some key aviation generals, and with their support he approached the Defence Minister of the newly established Spanish Republic [3]. Politically the time was very good, since the new Government wanted to strengthen the relationship with Central and South America.

Thus, the objectives of the flight were: to establish a new route between Spain (i.e., Europe) and America; to consolidate the cultural and economic ties with Cuba and Mexico; and to show the capability and competence of Spanish aviation in the record-breaking race of those years.

The flight was prepared at Cuatro Vientos airfield, since it had all the major facilities that were needed $[3,5,6]$ : the Aviation Meteorological Service; the School of Observers and Navigators; the Central Maintenance Facility; and a large wind tunnel, one of the main laboratories of the new-born School of Aeronautical Engineering [7]. All crucial considerations were addressed at the highest level. For example, the modifications to the airplane were made by CASA, engineers, Miguel Guinea, José Servert and Luis Larrauri, under the supervision of Luis Sousa Peco, CASA Director; the airplane was tested by Genaro Olivié, chief of the Aerodynamics Laboratory; the meteorology of the route was assessed by Lt. Col. José Cubillo, following the CINA (Comité International de Navigation Aérienne) criteria, which required the complete mapping of the Atlantic Ocean (winds, temperature, isobars, storms, etc.) at latitudes between 10 and 50 degrees North, etc.

Finally, a route was selected from among the eleven studied: Seville, the Portugese Madeira Islands, Puerto Rico, Santo Domingo, Cuba and Mexico. A certain advantage of this route, which extended more than $6000 \mathrm{~km}$ over water, was the possibility of using Madeira and Puerto Rico as landing areas along the path (but these areas were $3000 \mathrm{NM}$ apart), as well as the suitability of several Cuban airfields for landing, once arrived there. Interestingly, this route is almost exactly followed by present-day jets in their flight from Western Europe to the Caribbean region $[5,6]$.

Captain Barberán found a very good and experienced first pilot for this raid: Lieutenant Joaquín Collar. The preparation included a series of night flights onboard an unmodified Bréguet XIX within the Iberian Peninsula, and some flights to the Canary Islands and the West African coast [5, 6].

\section{The Bréguet XIX Super TR "Cuatro Vientos"}

The airplane selected for the Spain-Cuba flight was, logically, a Bréguet XIX sesquiplane specially prepared and modified by CASA for the purpose [8, 9]. Like its predecessor, the Bréguet XIV, the XIX had been designed by Louis Vuillierme. It was exhibited for the first time in November 1921 at the Aeronautics Salon in Paris, although its first flight took place in March 1922 [4]. The original version had an empty weight of $1387 \mathrm{~kg}$, a maximum take-off weight of $2500 \mathrm{~kg}$, powered by various engines from 400 to $500 \mathrm{CV}$, which allowed it to reach about $215 \mathrm{~km} / \mathrm{h}$ of maximum speed, a ceiling above $7000 \mathrm{~m}$ and a range of some $800 \mathrm{~km}[8,10]$. Many countries, e.g., France, Spain, Belgium, Yugoslavia, China and Argentina, had this aircraft the basis for their air forces in the 1930s $[4,8,9]$.
From the very beginning, because of its excellent capabilities and flight qualities, this airplane was used in some long distance attempts; for example the Madrid-Manila 18 stage flight in $1926[3,4]$. The incorporation of two extra fuel tanks and a more powerful engine in 1924 increased the range and led to the GR (Grand Raid) version. An extra fuel tank between the engine and the cockpit resulted in 1926 in the TR (Transatlantique) followed in 1927 by the Super TR or Superbidón version, which carried more than 5000 litres of fuel [4-6]. Fig. 1 depicts a two-view drawing of the aircraft. All these versions were employed in some important raids in the late 1920s and early 1930s, like the already cited flights by Costes and Bellonte in 1930, piloting the "Point d'Interrogation" from Paris to New York [2, 10, 11], and the flights of Iglesias and Jiménez on board "Jesús del Gran Poder" from Madrid to Baghdad in 1928 and from Seville to Bahia and other South American cities in 1929 [3, 4].

Due to the extremely long distance to be flown, the airplane required some modifications to increase the specific range, essentially by improving the aerodynamics, in the wings, fuselage and everywhere else. CASA engineers worked side by side with aerodynamicists of the Cuatro Vientos wind tunnel $[5,6]$, which resulted in an enlargement of the wingspan, an increase in the wing gross area, fairing of the main landing gear and, finally, fairing and closing the cockpit for both pilot and navigator. Various modifications were also carried out in the Hispano Suiza engine.

The enormous fuel tank (bidón, at it was named) between the engine and the cockpit also posed major problems, since it had to be part of the structure and had to transmit the stresses and forces from the engine to the rest of the airframe. A quick discharge pump was installed, so that the plane could float in the sea in case of ditching.

Table 1 shows the main differences between the ordinary Bréguet XIX and the Superbidón airplane. To be specially

Table 1: Main data of Bréguet XIX airplanes

\begin{tabular}{|l|c|c|}
\hline & $\begin{array}{c}\text { B XIX, } \\
\text { Spanish series }\end{array}$ & $\begin{array}{c}\text { B XIX } \\
\text { Cuatro Vientos }\end{array}$ \\
\hline Engine & Elizalde A4 & $\begin{array}{c}\text { Hispano Suiza } \\
\text { 12 Nb }\end{array}$ \\
\hline Maximum power $(\mathrm{CV})$ & 450 & 720 \\
\hline Wingspan $[\mathrm{m}]$ & 14.83 & 18.30 \\
\hline Length $[\mathrm{m}]$ & 9.51 & 10.70 \\
\hline Wing area $\left[\mathrm{m}^{2}\right]$ & 50 & 59.97 \\
\hline MTOW $[\mathrm{kg}]$ & 2300 & 6375 \\
\hline Empty weight $[\mathrm{kg}]$ & 1387 & 1900 \\
\hline Wing loading $\left[\mathrm{kg} / \mathrm{m}^{2}\right]$ & 46 & 106.4 \\
\hline Fuel capacity $[\mathrm{l}]$ & 440 & 5325 \\
\hline Oil capacity $[\mathrm{l}]$ & - & 250 \\
\hline Maximum speed $[\mathrm{km} / \mathrm{h}]$ & 214 & 230 \\
\hline Cruise speed $[\mathrm{km} / \mathrm{h}]$ & 175 & 190 \\
\hline Range $[\mathrm{km}]$ & 800 & Est. 8500 \\
\hline
\end{tabular}


noted are the increased wing span, wing loading, and useful load.

All controls and most flying instruments were duplicated, which was very important not only to share the piloting workload on an extremely long flight, but also in the case of sudden sickness as happened in the middle of the raid. The plane incorporated engine indicators (RPM, oil and fuel manometers, oil and water thermometers, and fuel quantity), flying indicators (anemometer, variometer, altimeter, artificial horizon, turn-and-bank, pitching angle, and clock) and navigation instruments (compass, chronometers, sextants, etc). The cockpit could be open in flight to allow the the use of astronomical instruments and the firing of smoke and luminous torches, thus providing information on the winds and bearing shifting $[5,6]$.

A two blade, fixed pitch propeller of $3.1 \mathrm{~m}$ diameter and a Hispano Suiza $12 \mathrm{Nb}$ engine, derived from the HS 12Lb, provided power and thrust to pull the aircraft in the mission [11]. It is important to note that, as in other long distance flights, the fuel was a mixture of gasoline (80\%) and benzol (20\%), which provided the minimum specific fuel consumption and detonation free operation, which was crucial to avoid engine failures $[5,6]$.

The total cost of the flight, including all previous studies, the airplane itself, spares sent to Cuba, etc., was financed by the Spanish Ministry of War (official name in 1933). The airplane, numbered 195 in the Spanish production line, had a cost of some 80.000 pesetas, apart from the engine, about double the cost of an ordinary Bréguet XIX [3]. Completed on 15 April 1933, it flew more than 50 hours in May to check the flying qualities and in order to familiarize the pilots with night flying $[5,6]$.

\section{Aerodynamics and performance of the "Cuatro Vientos"}

Modeling the aerodynamics and the performance of historical airplanes is similar to the preliminary design phases of the project for a new aircraft, with the main advantage of knowing beforehand the configuration and that the airplane is airworthy, but the drag polar and other relevant features are uncertain and can only be estimated. For various reasons, not the least important being two World Wars and a dramatic Civil War in the Spanish case, most plans and details have been lost; even of those airplanes proudly shown in national museums. And this is tone of the Bréguet XIX type: the Paris and Madrid Air Museums, among others, exhibit well preserved and beautiful models, but the available technical data is very scarce indeed.

In the present investigation the first step was to identify the airfoil. This was carried out with the help of a few construction plans (and photographs) that depicted the airfoil shape with high precision. Later, by comparison with the geometric data of many airfoils included in technical reports of the 1920s, a perfect matching was found to the Halbronn 3, a relatively thin airfoil ( $8 \%$ ) developed in France and tested in the Eiffel wind tunnel in 1916 [12]. This airfoil had a rather symmetric drag polar, negligible lift at zero angle of attack and a maximum lift over drag ratio near 20 at an angle of attack of about $5^{\circ}$.
The next step was to estimate the drag polar of the complete airplane. A common drag polar with a parasitic component and a parabolic term depending on the lift coefficient is used $[13,14]$

$$
C_{D}=C_{D 0}+K C_{L}^{2}
$$

The first term on the right hand side is the sum of all contributions from the braced, wired wing, the fuselage, empenage, landing gear and engine cowling. In the present work this has been estimated as [14]:

$$
\begin{aligned}
C_{D 0}= & \left(C_{\mathrm{fiv}} F_{\mathrm{fw}} S_{\text {wetw }} / S+C_{\mathrm{fB}} F_{\mathrm{fB}} S_{\mathrm{wetB}} / S\right) I_{\mathrm{f}}+ \\
& +C_{\mathrm{fe}} F_{\mathrm{fe}} S_{\text {wete }} / S+C_{\text {Dmis }} S_{\text {mis }} / S,
\end{aligned}
$$

where $C_{\mathrm{f}}$ are friction coefficients, $F_{\mathrm{f}}$ form factors and $S_{\text {wet }}$ exposed area of wing, body and empenage, $S$ the wing area, and the last term accounts for the drag produced by the cowling, windshield, landing gear and struts.

The friction coefficients were computed at the Reynolds number corresponding to $190 \mathrm{~km} / \mathrm{h}$ and $1000 \mathrm{~m}$, with the transition from the laminar to the turbulent boundary layer at $15 \%$ chord. All geometric data were measured on production plans and three-view drawings. The result is $C_{D 0}=0.00148$, which gives an equivalent parasitic area $\left(C_{D 0} S\right)$ of $0.89 \mathrm{~m}^{2}$, just on the lower end of the 0.9 to $1.7 \mathrm{~m}^{2}$ range typical of most biplanes of this period [15], as it should be for a distance record breaking aircraft. Interestingly, the increase in drag produced by the voluminous tank in the front fuselage is more than compensated by the increase in wing area.

The lift dependent component was estimated according to classical biplane theory $[16,17]$, plus a correction for trim drag and viscous induced drag; this last is known from the airfoil data. The parabolic parameter is

$$
K=S(1+\delta) /\left[\pi \mathrm{e}\left(\lambda b_{1}\right)^{2}\right]
$$

where $S$ is the wing area, e is the Oswald factor for the spanwise lift distribution, $\lambda$ a parameter depending on the relative sizes and vertical separation between planes, $b_{1}$ the span of the upper wing, and $\delta$ an efficiency parameter related to both the viscous induced drag and the trim drag [13, 14].

Numerically the estimated drag polar is

$$
C_{D}=0.0148+0.101 C_{L}^{2} \text {. }
$$

With this parabolic polar the estimated maximum lift over drag ratio is 12.93 (at $C_{L}=0.383$ ), exactly matching the reported figure of 13 found in the wind tunnel [18]. As another check on of the correctness of the guessed drag polar, the estimated maximum speed at 0.9 MTOW and $1000 \mathrm{~m}$, with a propeller efficiency of 0.70 [19] is about $225 \mathrm{~km} / \mathrm{h}$, accurate enough for the present purpose.

Using biplane theory again $[16,17]$, the lift curve slope is computed to be approximately $4.5 \mathrm{rad}^{-1}$. According to production plans and documents, the wing was fitted to the fuselage at an angle of incidence of about $4.5^{\circ}$, very close to that corresponding to maximum $L / D$, providing a lift coefficient of 0.35 at zero angle of attack of the aircraft.

The main performance of a long distance flight is, precisely, the specific range. And also, in parallel, the speed, altitude and attitude to obtain in each moment the maximum distance per unit mass of fuel burnt. The vertical and horizontal equilibrium of forces gives 


$$
\begin{aligned}
& W=L=1 / 2 \rho V^{2} S C_{L} \\
& T=D=1 / 2 \rho V^{2} S C_{D},
\end{aligned}
$$

where $W$ is weight, $T$ thrust, $L$ lift, $D$ drag and $1 / 2 \rho V^{2}$ the dynamic pressure. The fuel consumption is

$$
\mathrm{d} m / \mathrm{d} t=-c_{P} P,
$$

where $c_{P}$ is the specific fuel consumption and $P$ the power delivered by the engine. The thrust of the propeller and the engine power are linked through [19]

$$
T V=\eta_{h} \eta_{m} P,
$$

where $\eta_{h}$ and $\eta_{m}$ are the propeller and mechanical efficiency, respectively.

The distance travelled is

$$
x=\int_{0}^{t} V \mathrm{~d} t=\int_{m_{f}}^{m_{i}} \frac{V \mathrm{~d} m}{c_{P} P}=\int_{m_{f}}^{m_{i}} \frac{\eta_{h} \eta_{m}}{c_{P} T} \mathrm{~d} m,
$$

which, taking into account Eqs. 5 and 6, can be rewritten as

$$
R=\int_{W_{f}}^{W_{i}} \frac{\eta_{h} \eta_{m}}{g c_{P}} \frac{\mathrm{L}}{\mathrm{D}} \frac{\mathrm{d} W}{\mathrm{~W}}
$$

known as Bréguet's equation for propeller-driven aircraft.

Assuming that $\eta_{h}, \eta_{m}$ and $c_{P}$ are constant, the best range is obtained when, for any given weight $W, L / D$ is maximum. This is equivalent to flying at a constant angle of attack [18]: in the present case at $C_{L}=0.383$, or $\alpha_{\text {fus }}=0.4^{\circ}$ all along the flight. Available engine data [11] shows that, although $c_{P}$ varied both with power and regime, the variation was moderate, even negligible, except during the last part of the flight, when the power required was only about $1 / 3$ that of the beginning. The consumption data for the flight reproduction has been scaled from HS 12Lb values [11].

\section{The mission profile}

The flying conditions on June 9-10 1933 were defined by aerodynamicists and engineers [18] as should be done at the present time. The altitude was limited by engine operation and cockpit temperature between 500 and $2000 \mathrm{~m}$. Since after take-off the wing loading was relatively high $\left(106 \mathrm{~kg} / \mathrm{m}^{2}\right)$, the setting was established at around $200 \mathrm{~km} / \mathrm{h}$ and $500 \mathrm{~m}$, corresponding to $C_{L}=0.58$; far from optimum conditions but still at $L / D=11.9$. The prescribed subsequent evolution of speed, altitude and engine regime was defined to reach the maximum specific range within the limitations of the engine operating envelope, meteorological conditions, etc [18].

Table 2 shows some key points obtained in the present investigation during the reproduction of this flight. When Barberán and Collar overflew Madeira they knew that they were ahead of schedule (5-10\%) but also that they had burnt between 15 and $20 \%$ too much fuel. They reacted by decreasing the power setting, adjusting the regime and speed, but continued a little too fast and a little too high. As shown in Table 3, the flight was almost always faster than planned, arriving at Camagüey in 40.4 hours, some 3 hours earlier than scheduled (i.e., $7 \%$ ). The reason for this is not known. The error in the angle of attack between optimum and
Table 2: Evolution of selected variables in the reproduction of the "Cuatro Vientos" flight

\begin{tabular}{|c|c|c|c|c|c|c|}
\hline $\begin{array}{c}T \\
\text { hours }]\end{array}$ & $\begin{array}{c}W i \\
{[\mathrm{~kg}]}\end{array}$ & $\begin{array}{c}V \\
{[\mathrm{~km} / \mathrm{h}]}\end{array}$ & $C_{L}$ & $L / D$ & $P(C V)$ & $\begin{array}{c}R \\
{[\mathrm{~km}]}\end{array}$ \\
\hline 0 & 6320 & 198 & 0.58 & 11.9 & 617 & 0 \\
\hline 5 & 5559 & 191 & 0.62 & 11.6 & 543 & 968 \\
\hline 15 & 4361 & 187 & 0.51 & 12.4 & 396 & 2848 \\
\hline 30 & 3042 & 180 & 0.40 & 12.9 & 263 & 5614 \\
\hline 39 & 2429 & 173 & 0.36 & 12.9 & 210 & 7235 \\
\hline 40.7 & 2324 & & & & & 7530 \\
\hline
\end{tabular}

guessed $C_{L}$ (in this reproduction) is only about $1.5^{\circ}$, and between guessed and prescribed by the Aerodynamics Laboratory only $0.5^{\circ}$, very difficult to assess with the instruments of that time.

The effect of this small speed off-set was worsened by the exigency of flying almost permanently at $1500 \mathrm{~m}$ for meteorological reasons, since for the drag polar and engine performance the best range would have required a four-step cruise, at 500, 1000, 1500 and $2000 \mathrm{~m}$, each one for some 10 hours. To keep the appropriate dynamic pressure, flying higher equalled flying faster, thus mismatching the prescribed optimum cruise conditions at any given time, with the corresponding effect in fuel consumption and aircraft weight, as shown in Table 3 . The flatness of the $L / D$ versus $C_{L}$ curve (given by the parameter values of Eq. 4) allowed the pilots to reach Cuba, but not Havana, the desirable landing point. From Camagüey to Havana the distance is $500 \mathrm{~km}$, requiring about $150 \mathrm{~kg}$ of fuel at the end of the journey, but the airplane had only some $80 \mathrm{~kg}$ left on landing at Camagüey.

Obviously wind effects have been considered in the present investigation but have to be discarded, since they cannot produce at the same time a faster flight (which is equivalent to having a tailwind) and a less efficient flight (burning

Table 3: Weight and speed evolution prescribed in 1933 and present estimation

\begin{tabular}{|c|c|c|c|c|}
\hline $\begin{array}{c}T \\
{[\mathrm{~h}]}\end{array}$ & $\begin{array}{c}W \text { est. } \\
{[\mathrm{kg}]}\end{array}$ & $\begin{array}{c}W \text { prev. } \\
{[\mathrm{kg}]}\end{array}$ & $\begin{array}{c}V \text { est. } \\
{[\mathrm{km} / \mathrm{h}]}\end{array}$ & $\begin{array}{c}V \text { prev. } \\
{[\mathrm{km} / \mathrm{h}]}\end{array}$ \\
\hline 0 & 6320 & 6320 & 198 & 196 \\
\hline 5 & 5559 & 5790 & 198 & 194 \\
\hline 10 & 4926 & 5210 & 192 & 192 \\
\hline 15 & 4361 & 4700 & 187 & 187 \\
\hline 20 & 3872 & 4250 & 184 & 180 \\
\hline 25 & 3441 & 3850 & 184 & 177 \\
\hline 30 & 3042 & 3500 & 180 & 170 \\
\hline 35 & 2690 & 3150 & 180 & 167 \\
\hline 40 & 2367 & 2900 & 173 & 158 \\
\hline 40.7 & 2324 & 2858 & 0 & - \\
\hline
\end{tabular}




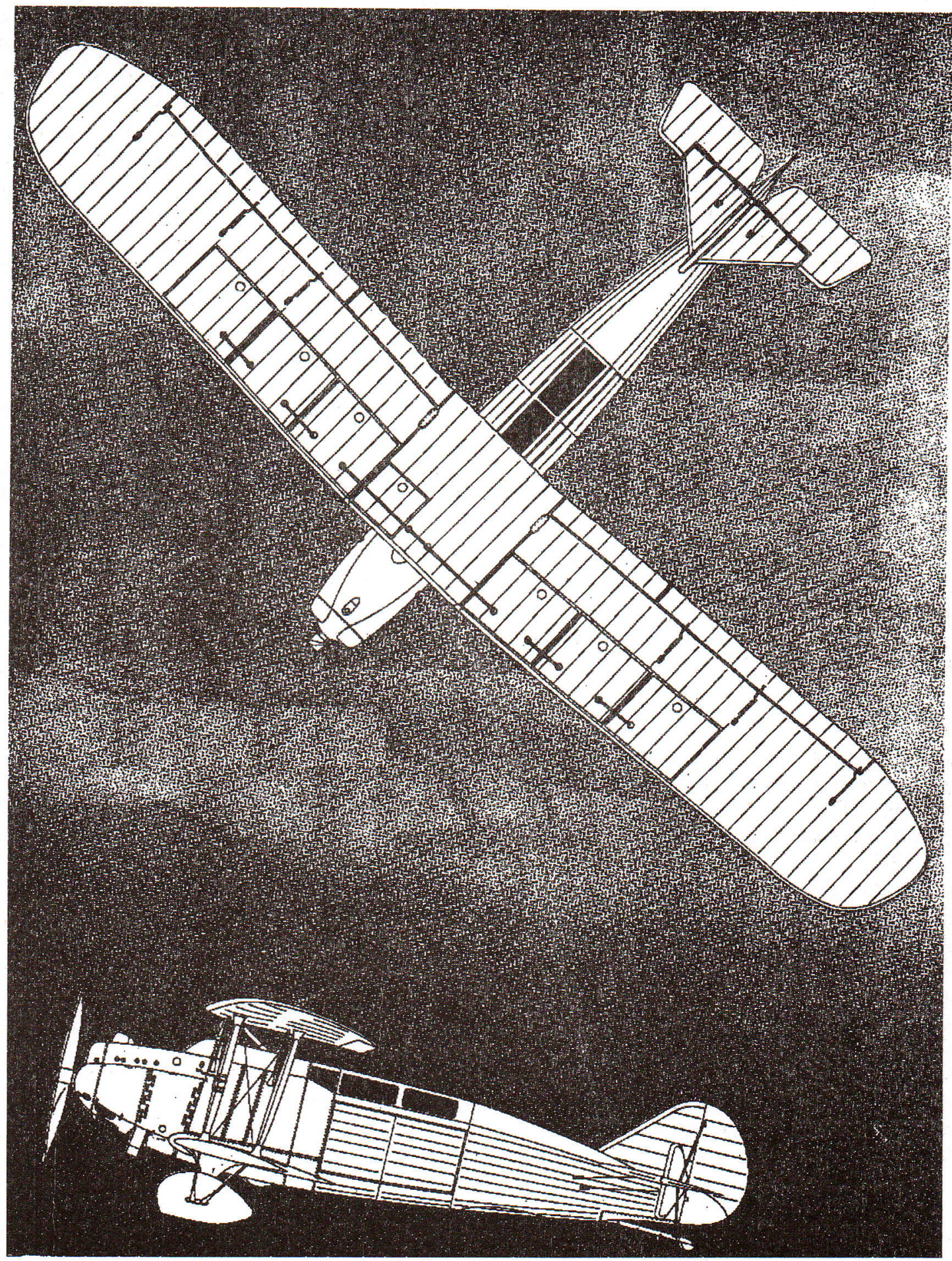

Fig. 1: Plan and side view of the Bréguet XIX Super TR "Cuatro Vientos", drawn by Miranda

more fuel). The already cited explanation based on a small mismatch in speed and altitude seems to be the most appropriate from the technical point of view. On the other hand, a crack was found in the enormous fuel tank after landing at Havana. Could this have been the cause of the apparent extra fuel burnt? Very likely not, for a crack leaking fuel over so many hours, partly in turbulent weather, would have implied a greater loss. The crack was probably produced in one of the two landings in Cuba: Camagüey or Havana, since the major stresses were concentrated around the engine-tank-wings-fuselage joint $[5,6]$.

\section{Final considerations}

The aerodynamic and performance methods developed over decades for airplane design are very accurate indeed. Accurate enough to allow an in-depth study of all circumstances of the main flights of the golden years, and to fully 
understand the technical reasons behind the preparation and execution of these flights. Part of our current knowledge is thus due to the airmen whose flights made possible the advancement of aviation. And so we are indebted to all of them and the study of their endeavours deserves our enthusiasm.

The "Cuatro Vientos" flight was one of the greatest raids of all time: more than $7500 \mathrm{~km}$ non-stop, mainly over water. The precise and exhaustive preparation, including the selection of aircraft, engine and route, represented an extraordinary achievement, never repeated and extremely difficult even with latest technology. The great effort made by Barberán and Collar was warmly recognised on their arrival in Havana and around the world, during the fortnight of the raid. However, their glory was sadly obscured by the accident that occurred a few days later, on June 20 1933, on their way to Mexico City. The remains of the aircraft and the pilots have never been found.

\section{Acknowledgement}

Dr. González-Betes, a retired aeronautical engineer, and member of the Historical Aeronautical Institute of Spain is indebted to various military and civil institutions that helped in many ways and also provided support for the preparation of this paper.

\section{References}

[1] Anderson, J. D.: A History of Aerodynamics and Its Impact on Flying Machines. Cambridge (UK): Cambridge University Press, 1997.

[2] Beaty, D.: The Water Jump. London (UK): Secker \& Warburg, 1976.

[3] Salas, J.: La ingeniería aeronáutica española y de ultramar. Madrid (E): AIAE y AENA, 1993.

[4] Sánchez Méndez, J., Delgado Rubí, J.: Dornier Wal and Bréguet XIX, Flying Together. Madrid (E): EADS CASA, 2000.

[5] González-Betes, A.: Gloria y tragedia del vuelo Sevilla-Cuba-Méjico. Aeroplano. Revista de Historia Aeronáutica, No 1, 1983.

[6] González-Betes, A.: Días de gloria y tragedia: el "Cuatro Vientos". In: "Grandes Vuelos de la Aviación Española". Madrid (E): IHCA, 1992, p. 255-281.
[7] Martínez-Val, R.: Aeronautical Engineering Education in Spain: Changing Needs in an Evolving Environment. AIAA Paper 96-0162. $34^{\text {th }}$ Aerospace Sciences Meeting and Exhibit, Reno (NV, USA), 1996.

[8] Warleta, J.: La serie Bréguet XIX en España. Aeroplano. Revista de Historia Aeronáutica, No. 1, 1983.

[9] Román, J. M.: CASA, the First 75 Years. Madrid (E): CASA, 1998.

[10] Anon.: Les avions de 1923. Revue General de L'Aéronautique, Vol. 3, No. 21, 1923, p. 1-20.

[11] Anon.: La préparation de la traversée. Bulletin Hispano Suiza, No. 12, 1930, p. 20-23.

[12] Anon.: Aerodynamic Characteristics of Aerofoils. NACA Report 93, 1921.

[13] Torenbeek, E.: Synthesis of Subsonic Airplane Design. Dordrecht (NL): Kluwer, 1982.

[14] Roskam, J.: Airplane Design.: Preliminary Calculation of Aerodynamic, Thrust and Power Characteristics. Ottawa (KA, USA): Roskam Aviation, Vol.6, 1987.

[15] Warner, E. P.: Airplane Design: Performance. $2^{\text {nd }}$ Edition. New York (USA): McGraw-Hill, 1936.

[16] Glauert, H.: Fundamento de la teoría del ala y de la hélice. Madrid (E): INTA, 1946.

[17] Lafita, F.: Aerodinámica aplicada. Madrid (E): Academia Militar de Ingenieros Aeronáuticos, 1945.

[18] Herrera, E.: Barberán y Collar. Madrid Científico, 1934, p. 197-199.

[19] Howe, D.: Aircraft Conceptual Design Synthesis. London (UK): Professional Engineering Publications, 2000.

Dr. Antonio González-Betes

phone: +34913366365

Fax: +34913366366

Prof. Rodrigo Martínez-Val e-mail:rmval@dva.upm.es

Departamento de Vehículos Aeroespaciales

ETSI Aeronáuticos

Universidad Politécnica de Madrid

28040 Madrid, Spain 